\title{
NOTES ON AUSTRALIAN EARTHWORMS. PART IV.
}

\author{
By J. J. Fletcher, M.A., B.Sc.
}

Quite recently through the kindness of Messrs. R. T. Baker, Alex. Morton, and H. J. Fletcher, I have received most valuable additional material enabling me in this paper to give a preliminary account of six new species of earthworms, of which four are from Gippsland, Victoria, one is from Tasmania, and one from New South Wales. Two of these especially comprise individuals of such fine and robust proportions as to present very favourable subjects for detailed examination. At present I merely give diagnoses of the species, such as I hope will enable them to be satisfactorily identified, reserving a fuller account of them until I come to review the whole. This course, I think, advantageous because I have not yet exhausted my stock of material, and certain characters-for instance those of the seymental organs, calciferous glands, spermathecæ-which, when only a few species had been examined, seemed likely to furnish characters of importance in discriminating genera, present, as more species come under notice, such more or less considerable variations within the limits of a single genus as to make it advisable to refrain from generalizations. and detailed comparisons until a general knowledge has been gained of as many species as possible.

Three of the new species-two from Gippsland and one from Tasmania-are referable to the genus Notoscolex, of which two species, both from New South Wales, have been hitherto described. Now that it is shewn to extend to Tasmania and Victoria, and comprising as it does the largest and finest Australian earthworms yet recorded-with the exception of Megascolides australis of McCoy-it bids fair to rank as one of our most characteristic genera. Further search will probably show it to be of still wider 
distribution, and it is not unlikely that the large, as yet undescribed, worms known to occur in Queensland and on the Manning, to which reference has already been made, also belong to it.

Another of the new species (Cyptodrilus mediterreus) inhabits the north-western interior of this colony, my specimens having been found on the banks of the River Darling between Bourke and Brewarrina. No species has hitherto been recorded from so far inland as this; and its occurrence is of interest as showing that the dry interior, at any rate in proximity to rivers, is not destitute of earthworms, though remote from them, as far as I can learn at present, worms seem to be very scarce or are entirely wanting.

Owing to the large size of the Tasmanian and the largest Gippsland worms, and to their very favourable condition for examination-the breeding functions being in abeyance-what I take to be the true testes were found without any difficulty; and subsequently, knowing what to look for, similar bodies were recognised in the smaller species (doubtfully in the Cryptodrilus) though in these in all the specimens examined the testes were obscured by masses of spermatozoa crowding the somites which contain them, whereas in the largest worms these segments were clean and empty. In the Tasmanian Notoscolex, of which I had the opportunity of examining fresh specimens, the testes are two pairs of small cellular masses, each made up of an inner solid portion attached at one point to the mesentery, and of an outer portion consisting of numerous short radiating filaments. In the Gippsland worms they were evidently of a similar character though, in the specimens dissected, flattened and squeezed out of shape owing to violent contraction. The testes are in segments $\mathrm{x}$ and $\mathrm{xI}$, attached low down to the posterior faces of the mesenteries between $\mathrm{IX}$ and $\mathrm{x}$, and $\mathrm{x}$ and $\mathrm{XI}$, corresponding in position with the ovaries in XIII, each pair situated opposite to, in front of, and in all the specimens dissected quite free from, the pair of ciliated rosettes in the same segment.

A re-examination of the other Australian species will probably show that a similar arrangement obtains in all of them. The bodies referred to with some doubt in my previous descriptions as 
" testes," therefore, should now in all probability be regarded as vesiculæ seminales. Their usually racemose character, their situation and remoteness from the ciliated rosettes, together with the fact that when the worms are sexually active the segments containing the ciliated rosettes are crammed with spermatozoa, have previously helped to leave me in doubt as to their real nature, and to overlook the true testes.

I have to thank the gentlemen already named for their kindness and trouble, and also Mr. Hugh Copeland, Junr., who lent Mr. Baker a helping hand.

\section{Notoscolex Gippslandicus, n. sp.}

A young (spirit) specimen is $37 \mathrm{~cm}$. long, $13 \mathrm{~mm}$. broad; a large but very soft adult specimen is 4 feet 1 inch ( $1 \cdot 23$ metre) long and $17 \mathrm{~mm}$. broad; number of segments about 500.*

Prostomium broad, depressed, marked anteriorly and inferiorly with about seven somewhat irregular grooves, not dividing the buccal ring but looking like a forward projection of its superior region. The buccal ring all round divided right across by a number of longitudinal grooves, giving it a ribbed appearance; divided into two annuli, the anterior annulus again subdivided in the dorsal region by two shallow transverse grooves just behind the prostomium. Body cylindrical ; superiorly especially anteriorly of a darker colour; clitellum still darker (purplish).

* These large worms are so brittle that it is difficult to extract whole specimens from their burrows ; hence the above-mentioned two are my only complete specimens. The following are the measurements of other incomplete examples :-

(a) Fragment (very soft)

No. of segments. Length.

Breadth.

(b) Complete all but preclitellar segments (very soft) 460 3ft.

(c) Young specimen, nearly complete..

468 3ft. 9in.

(d) Fragment of a large specimen..........

402

335

(e) $45163.5 \mathrm{~cm}$. (25 in.) $22 \mathrm{~mm}$. (f) Young specimen, nearly complete ... $490 \quad 36.2 \mathrm{~cm}$. $13 \mathrm{~mm}$.

Hence it would appear that very large individuals are from 2-3ft. long when contracted, and, probably, from 4-6ft. long when living and extended. 
The buccal ring rather broad (from before backwards); the second segment narrower, ribbed like the buccal ring, and faintly bi-annulate; each of the next three segments broader (from before backwards) than the one which precedes it; all of them divided into two principal annuli by a well-marked groove, the anterior annuli less distinctly again sub-divided into two; from segments VI to about XIV the maximum of length is reached, and these segments are usually very conspicuously tri-annulate, or some or all of the annuli may be subdivided into two, giving altogether six annuli to a segment; the next seven segments successively diminish slightly in breadth (from before backwards), after which they are of nearly uniform width for the rest of the body, and are faintly tri-annulate.

Clitellum wanting in the smallest specimens, fairly developed in one specimen, and distinctly indicated in all the large specimens by a difference of colour and by a slight glandular development; commencing with the middle or posterior annulus of xIII and including $\mathrm{xxI}$ (that is eight complete segments in addition to part of xIII) ; complete all round except for the intersegmental areas on the posterior ventral portion now to be mentioned. Between XVII and xvIII, extending on to the posterior margin of the former and the anterior margin of the latter is a slightly swollen area or ridge of a lighter colour, about $2 \mathrm{~mm}$. in width from before backwards (as it appears in an ordinary spirit specimen), and about $13 \mathrm{~mm}$. from side to side extending outwards a little beyond (about $2 \mathrm{~mm}$.) the second seta on each side; at the junction of XVIII and XIX a somewhat similar but broader (from before backwards) and more depressed area separated from the preceding one by a narrow portion of the middle annulus of the segment, and near its extremities shewing two very slight papillæ which are about $9 \mathrm{~mm}$. apart, and about in line with the setæ of the second row on each side; at the junction of $\mathrm{xIx}$ and $\mathrm{xx}$ an area similar to the first-mentioned one.

Setæ of the ordinary shape, with a slight sigmoid flexure, about -49 mm. long, with a slight enlargement at about $\frac{1}{3}$ from tree tip ; in eight longitudinal rows forming four series of pairs, the setæ 
of the two outer pairs further apart (about twice) than those of the inner pairs ; the first row on each side about $3 \mathrm{~mm}$. from the median ventral line, the second about $1 \mathrm{~mm}$. from the first, the third about $3 \mathrm{~mm}$. from the second, the fourth about $2 \mathrm{~mm}$. from the third. The setæ are easily seen with a lens, and are usually plainly visible to the naked eye.

Male pores two, on xvin on slight papillæ about $9 \mathrm{~mm}$. apart and about in line with the second setæ. The two oviduct pores are on XIV, rather close together, ( $3 \mathrm{~mm}$. apart), in front but considerably ventrad of the inner rows of setæ. Spermathecal pores two pairs, ventral in position, between VII and VIII, and viII and Ix but just on the posterior margins of VII and vIII, about $7 \mathrm{~mm}$. apart, and just dorsad of the second row of setæ on each side.

Dorsal pores commence between about XIX and $x \mathrm{x}$; the first two or three less distinct than the others and sometimes hardly noticeable; nephridiopores not discernible.

Alimentary canal : the very muscular pharynx occupies the first four segments and has immediately behind it the first complete mesentery ; the very short œsophagus and the gizzard are in segment $\mathbf{v}$; in segments XII-XVIII the lumen of the canal is dilated and its walls are very vascular, but there are no diverticula; the large intestine commences in XIX.

Genitalia: true testes two pairs, in segments $\mathrm{x}$ and $\mathrm{xI}$, small filamentous cellular masses attached low down to the posterior faces of the mesenteries between segments $\mathrm{IX}-\mathrm{X}$ and $\mathrm{X}$-XI and corresponding in position with the ovaries in XIII ; opposite the testes, and therefore in segments $\mathrm{x}$ and $\mathrm{xI}$, but quite free and independent of them in both the specimens dissected (in which evidently the breeding functions were in abeyance) are the two pairs of ciliated rosettes lying immediately in front of the posterior mesenteries of the segments which contain them; in segments XII and XIII (not the anterior pair in IX or XI as usual) two pairs of racemose vesiculæ seminales, membranous sacs containing spermatozoa in various stages of development, attached to the anterior mesenteries of the segments on each side of the intestine, (a third pair of somewhat similar-looking but very much smaller bodies in 
a corresponding position in XIV, whose identification is at present doubtful); the prostates are two long narrow pinkish bodies in segment xviII, each of them several inches long when unravelledand straightened out, convoluted and folded transversely with the long axis into a compact flat mass from which anteriorly comes off the genital duct which is fairly long and convoluted and entirely sheathed in a membranous envelope which extends on to and sheaths the prostate also, binding the transverse folds together, and two parallel bands of which in appearance almost like additional but incomplete mesenteries pass to the floor of the segment, the genital ducts lying between them; no penial setæ were met with, nor were the vasa deferentia visible in any part of their course.

The ovaries occupy the usual position in xIII; the oviducts commencing opposite to them in the same segment open to the exterior on the floor of the next one ; the two pairs of spermathecæ are in VIII and IX, and each of them presents externally three or four divisions, (1) a short proximal portion or stalk, (2) a middle very much dilated portion (3), a distal much narrower and shorter portion, (in one of the two specimens dissected this portion was not distinguishable), and (4) a rudimentary rather broad cæcum coming off from the stalk, its tip slightly serrate with four or five minute notches.

Mesenteries : the first ten complete mesenteries from the posterior one of segment iv to the posterior one of xIII are enormously thick, their anterior faces rather deeply concave, in contracted worms overlapping like a pile of saucers or cups, braced together and to the body wall by strong bands; the next two or three are a trifle thicker than those which follow, which are thin and transparent.

There are nine pairs of transverse hearts, the last pair in xIII, those of this and the preceding two or three pairs commencing superiorly by two narrow trunks, one from the dorsal vessel, and one from a supra-intestinal vessel. 
The segmental organs are minute tufts of glandular tubules distributed over the walls of the body-cavity, a hundred or so to a segment.

Hab. - Warragul, Gippsland, Victoria.

For the opportunity of describing this and the other three Victorian species I have to thank my friend and late colleague Mr. R. T. Baker of Newington College, who made a special visit to Gippsland in order to obtain material for me.

From Megascolides australis, a species described by Professor $\mathrm{McCoy}^{*}$, from the same district, and comprising individuals quite as large as those of Notoscolex Gippslandicus, the latter differs in the following, among other particulars:- the clitellum is complete all round and is situated more anteriorly; the setæ of the ventral pairs are not closer together than those of the outer pairs, and are of the ordinary character, not tapering throughout towards the free tip as in McCoy's figure; the dorsal pores commence after about segment $\mathrm{xIx}$, that is to say considerably in advance of segment XL.

I have heard from residents of Gippsland that these large worms were able to produce sounds, and Mr. Baker, whose attention $\mathrm{I}$ directed to this matter, tells me that in passing over the ground where these worms occur one does hear noises, which he considers may perhaps be due to friction of their bodies against the sides of the burrows, or to the sudden and forcible ejection of fluid from the dorsal pores, perhaps also to the suction of the air caused by a piston-like movement of their bodies, when the worms are disturbed by the vibration of the ground.

\section{Notoscolex Tasmanianus, n. $\mathrm{sp}$.}

A living specimen held up by the tail $1 \mathrm{ft} .10 \frac{1}{2} \mathrm{in} .(57 \cdot 2 \mathrm{~cm}$.) long; the same specimen crawling on the table 19in. long (48.3 cm.) by about $12 \mathrm{~mm}$. average breadth; after being killed with chloroform $24.5 \mathrm{~cm}$. long, breadth from 12-21 mm. Very

* Prodromus of the Zoology of Victoria, Dec. I, (1878), p. 21, pl. 7. 39 
large living worms when fully extended are over $2 \mathrm{ft}$. long. A dozen rather contracted spirit specimens are from $20-25 \mathrm{~cm}$. long, with a breadth of 19-24 mm. Number of segments about 200 .

In living specimens four differently coloured regions may be recognised, (1) the flesh-coloured preclitellar region, (2) the yellower inclining almost to orange clitellum, (3) the greater part of the remainder of the body purplish or bluish white or grey, the intersegmental furrows purplish, (4) a posterior region tinged with brown; spirit specimens may appear more or less tinged with brown throughout.

Body cylindrical; when strongly contracted both extremities very obtuse; when extended tapering steadily anteriorly from about segment IX forward.

Prostomium slightly depressed, divides the buccal ring for about $\frac{1}{3}$, marked with two or three longitudinal grooves anteriorly and inferiorly so as to give it a ribbed appearance. The buccal ring ribbed all round. Up to about the ninth the segments become gradually broader (from before backwards), after xIII diminishing again for a few segments and then remaining constant; the second segment bi-annulate, the rest triannulate, but in the first three or four of these the anterior annular groove more or less incomplete and less conspicuous than the posterior one; the preclitellar segments especially in the region where the mesenteries are thick, better defined, broader and more distinctly annulate, the bodywall in this region enormously thick and muscular.

Setæ of the ordinary character, stouter and a little longer (0.66 mm.) than in the preceding species, the free portion faintly circularly striate; in eight longitudinal rows of which the innermost on each side is about $2 \mathrm{~mm}$. from the median ventral line; the second on each side $2 \mathrm{~mm}$. from the first; the third on each side about $4 \mathrm{~mm}$. from the second ; the setæ of these six rows, which are straight and fairly parallel, a little closer together in the anterior portion of the body; the fourth row on each side in nearly every specimen variably sinuous, sometimes extremely so, the setæ from $3-8 \mathrm{~mm}$. from the corresponding ones of the third 
rows, sometimes alternating irregularly, sometimes a few nearly straight, at other times forming an ascending series of five or six, the amount of the sinuosity varying within considerable limits in the different individuals ; in one specimen these rows are, however; nearly straight.

Clitellum absent in some specimens, partially developed in others, and enormously thick in a few, including segments xIV-XXII, and in addition part of xIII, usually its middle and posterior annuli; when only partially developed, the glandular development is wanting in the median ventral line for a space extending outwards on either side a little beyond the second row of setæ, but in other cases the ventral surface not occupied by the ridges is modified so as more or less completely to surround these, but for which the clitellum would be complete all round. Between XIV and $\mathrm{xV}$, and between each pair of succeeding segments as far back as XXI-XXII is a lighter-coloured ridge taking in the last annulus of the anterior and the first annulus of the posterior of the two segments between which it occurs, and extending outwards on each side a little beyond the second row of setæ and to the ventral margins of the girdle, except in the case of the fourth and fifth which do not extend outwards so far and between which is a slight ridge on which are situated the two small papillæ carrying the male pores, which correspond in position with the intervals between the first and second setr on each side, or are slightly ventrad of the latter.

The two oviduct pores on xIv, in front and a little ventrad of the first seta on each side, and about $3 \mathrm{~mm}$. apart.

Spermathecal pores five pairs, a pair between each two segments from IV to IX, ventral in position and in line with the first seta on each side.

Dorsal pores commence between XII and XIII.

Nephridiopores form a sinuous series of pores situated close to the anterior margins of the segments commencing with segment II ; on the whole they may be said to be dorsad of the fourth row of setæ, but as both the setæ of this row and the nephridiopores 
independently form sinuous series, the latter may on some segments be in line with or ventrad of the outermost setæ on these segments, and in a few instances the nephridiopores were in line with the third seta on each side. Some of them are as much as $5 \mathrm{~mm}$. dorsad of the fourth seta, and not very far from the median dorsal line; sometimes they alternate irregularly for some distance, at other times they form short ascending and descending series.

Alimentary canal: the very muscular pharynx and the short œsophagus occupy about the first four segments; the large gizzard is in $\mathbf{v}$; in the next two segments the small intestine is narrow and white, while in segments VIII to xVI, especially in the last two or three of these, the portion in each segment is globularly dilated and very vascular, some of them probably functioning as calciferous glands (in one specimen white masses effervescent on the addition of acid were found in all but the first of these segments), but there are no kidney-shaped diverticula as in $N$. camdenensis; the large intestine commences about XIX, without any very marked increase in calibre, much folded and convoluted in contracted worms.

Genitalia: vesiculæ seminales two pairs of racemose sacs, a pair in each of segments IX and XII, the first pair attached to the anterior face of the mesentery between $\mathrm{Ix}$ and $\mathrm{x}$, the hinder pair to the posterior face of that between XI and XII ; testes in $\mathrm{x}$ and XI, in each of which segments also is a pair of ciliated rosettes ; prostates two, in xvin, or partly in this and partly in the next segment, long and narrow, a few times folded, proximally continuous with the short genital duct; no penial setæ were met with, nor were the vasa deferentia visible. Ovaries in the usual position in XIII ; the oviducts commence opposite thern in XIII and open to the exterior in the next segment: spermathecæ five pairs, one pair in each of segments V-IX, pear-shaped stalked pouches without cæca, opening anteriorly.

There are nine pairs of "hearts" of which the last pair is in xIII, this and the three preceding pairs very large and arising partly from a secondary small supra-intestinal vessel commencing in IX. 
From the posterior one of $\mathrm{v}$ to the posterior one of xII the mesenteries are very thick; they are braced together and to the body wall by very thick cords, very noticeable in the case of the first complete one-the anterior one of $\mathbf{v}$.

The segmental organs comprise a pair of coiled tubules in each segment after the second, each tubule consisting of a proximal fairly straight thick-walled portion longer (sometimes twice as long or even more) in some segments than in others according to the position of the pore, a short vesicular middle portion whose distal end lies close to the nerve cord, and a long ciliated glandular distal portion folded on itself and convoluted so that the loop reaches outwards a little beyond the commencement of the middle portion, while its ciliated anterior extremity, which is without any conspicuous "funnel," lies somewhere near the junction of the middle and distal portions.

Hab.-Thomas's Plaius, N. E. Tasmania.

For all my examples of this fine species I am indebted to Mr. Alex. Morton, Curator of the Tasmanian Museum, who very kindly sent me both living and spirit specimens, discovered by $\mathrm{Mr}$. Bernard Shaw, Inspector of Police. The worms of this species are readily distinguishable by the five pairs of spermathecæ, and the numerous clitellar ridges ; they are remarkable for their thickness, for while they are much shorter than, and comprise less than half the number of somites met with in, the big Notoscolex from Gippsland, they fairly rival it in thickness; and are much more robust and massive than the worms of the smaller Notoscolex, than which they have fewer somites.

\section{Notoscolex tuberculatus, n. sp.}

A dozen (spirit) specimens vary from $9 \mathrm{~cm}$. (a young individual) to $25 \mathrm{~cm}$. in length, $5-7 \mathrm{~mm}$. in breadth ; the number of segments from about 250-280.

Colour (in spirit) uniformly pale flesh-coloured; body cylindrical. 
Prostomium broad, slightly depressed, only partially dividing the buccal ring (about half). Segments II-Iv biannulate, after which they are tri-annulate, the anterior annular groove for a few segments less conspicuous.

Setæ in eight longitudinal rows, forming four series of couples ; the two innermost rows about $3 \mathrm{~mm}$. apart; the second row on each side slightly less than $1 \mathrm{~mm}$. from the first; the third about $2 \mathrm{~mm}$. from the second; the fourth about $1 \mathrm{~mm}$. from the third, the distance between these slightly greater than that between the setæ of the first couple.

Clitellum (in one case) commences with xiII, (the anterior or even this and the median annuli not included in all of them) and includes the first and second annuli of xviII (probably the whole of this segment when the worms are breeding), thick and complete all round except for the fossæ on its posterior ventral portion; absent altugether in some of the specimens, and among some of the others in various stages of development as regards thickness, and the amount of xIII included in it. In specimens in which the girdle is not fully developed on the ventral surface of the anterior annuli of segments XVII-XxII there is a dumb-bell-shaped fossa extending outwards a little beyond the inner couple of setæ on each side; in worms in which the girdle is better developed these areas come to occupy nearly the whole breadth (from before backwards) of the segments, their rims are thickened and in each of the large extremities there is a papilla probably with a pore; the second and third of these fossæ do not extend so far outwards as the others and their extremi ties become confluent, leaving a central eminence.

Male pores on two slight papillæ on the middle annulus of xvirI, not conspicuous (in my specimens), about in line with the intervals between the inner couples of setæ. Oviduct pores two, in front and ventrad of the first seta on each side.

Spermathecal pores two pairs, close to the posterior borders of the anterior annuli of VIII and Ix, just dorsad and in front of the first seta on each side. 
Dorsal pores commence between XII and XıII, not always visible on the clitellum; nephridopores not visible.

Alimentary canal : the pharynx occupies about the first four segments; the short esophagus leads to the large gizzard in $\mathrm{v}$; in segments $\mathrm{v}$ and $\mathrm{vI}$ are two pairs of conspicuous tufts of tubules which may be salivary glands; calciferous pouches seem to be absent but in XII and XIII the canal is globular and vascular possibly representing calciferous glands; the large intestine commences in XVIII.

Genitalia : two pairs racemose vesiculæ seminales, a pair in each of segments IX and XII ; testes and ciliated rosettes two pairs of each, in $\mathrm{x}$ and $\mathrm{xI}$; two prostates in XVIII, each of them a long narrow linear gland compacted into a mass, and proximally narrowing into the rather long S-shaped genital duct; the vasa deferentia not visible; lying beside the proximal portion of each genital duct is a pair of minute sacs, each containing a long tapering curved penial seta. The ovaries and oviducts have the usual situation and relations; spermathecæ two pairs, in viII and Ix, pear-shaped pouches, with a narrow stalk or duct about half as long as the pouch, at the junction with which is a small knoblike rudiment of a cæcum.

Six mesenteries commencing with the one between VII and vIII are thicker than the others.

The last pair of hearts is in XII.

The segmental organs are delicate folded tubules, a pair to each segment, except some of the anterior ones.

In segment $\mathrm{xVII}$, and also in $\mathrm{xx}$ and two or three following segments on either side of the nerve cord is a small white hemispherical elevation, in relation with the external copulatory papillæ.

Hab.-Warragul, Gippsland, Victoria.

The worms of this species are remarkable for their slenderness. In appearance at first sight they resemble those of several species of Cryptodrilus, or as the setæ are not conspicuous, and accessory copulatory structures are, even Perichceta Coxii.

The best of my specimens are only just intraclitellian, and no more; possibly when the girdle is fully developed it may include the 
whole of segment xvirr. Hence it seems to me that the chief difference between the genera Notoscolex and Cryptodrilus is becoming narrowed down to the question of segment XviII being included in the girdle. I begin to suspect therefore that when I come to revise the species already described, with additional material to work upon, it may be necessary to include the latter in the former genus, or at any rate to regard it as a sub-genus; and to deal with Didymogaster in a similar same manner, viz., to treat it as a subgenus of, or include it in Digaster. Under any circumstances the name Didymogaster will have to be changed, as, since I made use of it, I find that it is already pre-oceupied for a genus of insects.

Cryptodrilus mediterreus, $\mathrm{n}$. $\mathrm{sp}$.

Ten (spirit) specimens are from $7 \cdot 3$ to $11 \mathrm{~cm}$. long, $4-5 \mathrm{~mm}$. broad, and comprise from 130-150 segments. A young specimen $4 \cdot 2 \mathrm{~cm}$. long, and $2 \frac{1}{2} \mathrm{~mm}$. wide comprises 132 segments.

Colour above sooty-brown, darkest in the anterior portion of the body, especially in front of the clitellum, lighter below, the clitellum with a tinge of red or purplish. Prostomium slightly depressed (in spirit specimens), does not divide the buccal ring; the latter completely divided by a number of fine longitudinal groovings extending right across it.*

Segments are more or less completely tri-annulate after about segment IV.

Setæ in eight longitudinal rows, the first and second on each side ventral, the third lateral, the fourth dorsal; the first about midway between the second and the median ventral line, the third from the second about twice as far as the latter is from the first, the fourth about midway between the third and the median dorsal line and a little further from the third than this is from the second.

Clitellum comprises three complete segments, xIV-xVI, together with frequently a variable portion of the posterior annulus of xIII, and usually the whole of the anterior one of xvII ; complete all round.

* As one of the portions into which the buccal ring is so divided is immediately posterior to the prostomium, in some specimens it appears as though the latter completely divided the former; this however is not really the case. 
Male pores two, on conspicuous papillæ on xvIII, slightly dorsad of the second row of setæ on each side. Oviduct pores two, in front and a little ventrad of the first seta on each side ; spermathecal pores three pairs, a pair between each two segments from VI-IX, in line with the second seta on each side. Accessory copulatory structures comprise a swollen ventral portion of vi to IX ; a pair of circular swellings on the ventral surface of each of segments $\mathrm{x}$ and $\mathrm{XI}$; and on the anterior margin of XVIII and of XIX and ventrad of the male pores is what may be a pore on each side.

The nepridiopores are close to the anterior margins of the segments commencing with the second one, and form two irregularly alternating series on each side, one at the level of the fourth, the other at first at that of the third setæ, (the first two or three pairs are at the former level, and occasionally, especially in the anterior region, the pores may continue at the same level for several consecutive segments); behind the clitellum the inner rows are at the level of the second setæ, and are visible only on alternate segments, an arrangement which I am at present unable to reconcile with the presence of consecutive pairs of nephridia in this region.

Dorsal pores after segment $\mathrm{v}$ or vi.

Alimentary canal : the gizzard is in segment $\mathbf{v}$; each segment from $\mathrm{x}$ to XIII contains a pair of calciferous pouches, which lie at the side of and somewhat below the alimentary canal the overlying portions of which have the lumen dilated; the large intestine commences in xviII.

Genitalia : in each of segments XI and XII a pair of racemose vesiculæ seminales (very small in all the specimens dissected); segments $\mathrm{x}$ and $\mathrm{xI}$, which were partially filled with masses of spermatozoa, contain the two pairs of ciliated rosettes [and probably the true testes, but their identification was not perfectly satisfactory]; the two prostates are lobulated compressed bodies occupying part of four or five segments, xVII to $\mathrm{xx}$ or xxI ; the vasa deferentia join the prostatic ducts, which come off about the middle of the glands, a little way from the latter; 
the genital duct then gradually increases in calibre, and is bent in $U$-shape, the limbs lying close together, and the convexity of it looking backwards; beside the proximal portion of each genital duct is a pair of small white sacs, each of which contains a delicate tapering curved penial seta about $2.5 \mathrm{~mm}$. long, minutely spinose towards the curved tip. The ovaries and oviducts have the usual situation and relations: the three pairs of spermathecæ are in segments VII-IX, and are stalked pouches, each with a very rudimentary club-shaped cæcum coming off at the junction of the stalk and the pouch.

The last pair of hearts is in XIII.

The nephridia are two series of pairs of tubules; those corresponding with the outer rows of pores look like small vesicles, and are in alternate segments; those of the second series have the usual situation, and are delicate and convoluted, a pair in each segment except some of the anterior ones, but I have not succeeded as yet in finding a corresponding consecutive series of nephridiopores.

Seven mesenteries commencing with the anterior one of vII are thicker than the others.

Hab. - The banks of the Darling River between Bourke and Brewarrina, N.S.W.

The three pairs of spermathecæ at once distinguish this species trom those previously described. My specimens were sent to me by my relative Mr. H. J. Fletcher, who found one by accident, and obtained the others by digging for them.

\section{Pericheta Bakeri, n. sp.}

Of nine specimens three are fragmentary; length of six (spirit) specimens, most of them about halfgrown, from 47 to $92 \mathrm{~mm}$., breadth from 4 to $6 \mathrm{~mm}$.; number of segments from about 120 to 140. Colour dark reddish or purplish brown above, darkest in anterior part of the body, much lighter below, the change of colour anteriorly at the level of about the 6th seta on each side, further back at about that of the tenth. Prostomium completely divides the buccal ring, marked superiorly by a median longitudinal groove. 
Setre in the anterior region of the body longer, stouter and further apart, on the preclitellar segments 22 per segment; at about $\mathrm{xv}$ the number increases to 28 or 30 , and still further back to about 36 , but in some cases if not usually the last few segments seem to be smooth and setæ are not visible; in themedian dorsal and ventral regions is an interval devoid of setæ, the dorsal interval slightly the narrower, in each case between twice and thrice the width of an interval between two setæ in the same region. The rows of setæ are frequently not quite straight, though this may perhaps be due to unequal contraction of the parts of the body, or to the accidental absence of some of the setæ.

Girdle not developed in any of the specimens, but evidently comprising XIV-XVI together with a portion of each of segments XIII and XVII, as in nearly all the specimens the segments mentioned are differently coloured.

Male pores two, not on papillæ in any of the specimens, corresponding with the interval between the first and second setæ on each side. Oviduct pores two, in front and slightly ventrad of the first seta on each side. Spermathecal pores five pairs, on the anterior margins of segments $\mathrm{V}$-IX, ventral, in line with or slightly dorsad of the first seta on each side.

Dorsal pores commence after segment IV. Nephridiopores not visible. Accessory copulatory structures comprising pairs of pores, each pair usually on a ridge, at the junctions of XVII-XVIII, XVIII$\mathrm{XIX}, \mathrm{XIX}-\mathrm{Xx}$, and $\mathrm{xx}-\mathrm{xXI}$, the first two pairs ventrad of the male pores, the others in line with them.

Alimentary canal : the gizzard is in segment $\mathrm{v}$; in each segment from $\mathrm{IX}$ to $\mathrm{XIV}$ or $\mathrm{xV}$ the intestine has its lumen dilated and its walls vascular but there are no diverticula; the portion in XvI is very narrow, and the large intestine begins in xvII.

Genitalia : vesiculæ seminales two pairs, one pair in Ix and one in XII, the intervening segments containing the true testes and the ciliated rosettes as well as a large quantity of spermatozoa; the 
two prostates occupy xviII and xix, each of them being a long narrow body coiled into a compact mass, the duct coming off from the anterior portion of the gland, (the junction with the vas deferens not visible), the genital duct fairly long and $U$-shaped. The ovaries and oviducts have the usual situation and relations; the spermathecæ are five pairs of stalked pouches opening anteriorly in segments $\mathrm{V}$-Ix, each with a short but distinct club-shaped cæcum only about $\frac{1}{3}$ the length of the pouch. Lying beside the proximal portion of the genital duct is a small white body, its distal extremity attached to the body wall by a ligament; this is a sac containing a thin curved penial seta.

The segmental organs consist of small and delicate folded tubules, a pair in each segment except a few anterior ones.

The last pair of hearts in xII, this and the two preceding pairs the largest.

Hab.-Warragul, Gippsland, Victoria.

This is the only Australian species of the genus with five pairs of spermathecæ as yet described. The specimens were found in rotten $\operatorname{logs}$, and it was while searching for them that a specimen of Peripatus Leuckartii, Säng., (antea p. 450) was picked up.

\section{Pericheta dorsalis, n. $\mathrm{sp}$.}

Three (spirit) specimens are 56,88, and $95 \mathrm{~mm}$. long respectively, 7 , 6 , and $5 \mathrm{~mm}$. broad respectively, and comprise about $130 \mathrm{seg}$ ments.

Colour darker above and especially in the anterior portion of the body, reddish-brown, lighter below. The prostomium divides the buccal ring for slightly more than half.

Setæ for the first few setigerous segments 16 per segment, then increasing to 20 , still further back and just in front of clitellum 24 may be counted, while in the posterior region there may be about 30 . There is a well-marked ventral interval devoid of setæ, about twice (or a little less in front of girdle) the width of the 
interval between two setæ in this region; a well-marked dorsal interval also, somewhat narrower than the ventral one, about twice the interval between two setæ in the dorsal region.

Clitellum comprises three complete segments, XIV-XVI, and part of xvII, complete all round ; wanting in the smallest specimen.

Male pores on conspicuous papillæ, just ventrad of the third seta on each side.

Oviduct pores two, on xIV, one on each side of median line. Spermathecal pores four pairs, between each two segments from $\mathrm{v}$ to $\mathrm{Ix}$, in line with about the eighth seta (the rows of pores are not quite straight and there may be two or three setæ dorsad of them) and therefore dorsal in position, so that they are visible when the worm is looked at from above.

Dorsal pores commence after segment Iv. Nephridiopores not visible.

On the anterior margins of $\mathrm{x}$ and xvir a pair of circular depressions with raised and swollen margins, one on each side, corresponding with the intervals between the first and second or second and third setæ; these may be accessory copulatory structures.

Alimentary canal : the gizzard may be in $\mathrm{v}$, but being very large and the mesenteries behind it being very thin it seemed to be in VI ; from viII to XIV there are globular, vascular dilatations which are probably calciferous glands, but there are no diverticula ; the large intestine commences in xvII.

Genitalia : vesiculæ seminales three pairs, in IX, XI and XII ; true testes and ciliated rosettes two pairs, in $\mathrm{x}$ and $\mathrm{xI}$; prostates two, occupying part of two segments, XVIII and XIX ; genital ducts rather long, S-shaped ; the vasa deferentia join the prostatic ducts close to the prostates, the latter coming off just behind the anterior extremities of the glands. Ovaries and oviducts as usual ; spermathecæ four pairs, quite dorsally situated, of which the first pair is in VI and the last in $\mathrm{Ix}$, long slightly tapering pouches, each with a cæcum as long as or even slightly longer than itself. 
Six mesenteries commencing with the one between viII and Ix are noticeably thicker than the others.

The last pair of hearts in xiIr.

Minute inconspicuous tufts of tubules distributed over the walls of the body cavity seem to be segmental organs.

Hab.-Warragul, Gippsland, Victoria.

This species is readily distinguishable from $P$. fecunda, the only other Australian species having four pairs of spermathecæ and interrupted circles of setæ yet described, by the dorsal position of the spermathecal pores. 


\section{$2 \mathrm{BHL}$ Biodiversity Heritage Library}

Fletcher, J. J. 1887. "Notes on Australian earthworms. Part IV." Proceedings of the Linnean Society of New South Wales 2, 601-620.

https://doi.org/10.5962/bhl.part.29205.

View This Item Online: https://www.biodiversitylibrary.org/item/21749

DOI: https://doi.org/10.5962/bhl.part.29205

Permalink: https://www.biodiversitylibrary.org/partpdf/29205

\section{Holding Institution}

MBLWHOI Library

Sponsored by

MBLWHOI Library

\section{Copyright \& Reuse}

Copyright Status: NOT_IN_COPYRIGHT

This document was created from content at the Biodiversity Heritage Library, the world's largest open access digital library for biodiversity literature and archives. Visit BHL at https://www.biodiversitylibrary.org. 